\title{
The impact of oral anticoagulation on false lumen patency in acute type $\mathrm{A}$ aortic dissections
}

\author{
Oral antikoagülasyon kullanımının akut tip A aort diseksiyonlarında \\ sahte lümen açıklığı üzerindeki etkisi
}

\author{
Pelin Öztürk ${ }^{\circledR}$, Anıl Ziya Apaydın ${ }^{1}$, Engin Karakuş $\mathbb{C}^{2}$, Ali Önder Kılıç $\mathbb{B}^{3}$, Mustafa Özbaran ${ }^{1}$ \\ Institution where the research was done: \\ Medicine Faculty of Ege University, İzmir, Turkey \\ Author Affiliations: \\ 'Department of Cardiovascular Surgery, Medicine Faculty of Ege University, izmir, Turkey \\ ${ }^{2}$ Department of Cardiovascular Surgery, Bölge State Hospital, Batman, Turkey \\ ${ }^{3}$ Department of Cardiovascular Surgery, Tunceli State Hospital, Tunceli, Turkey
}

\begin{abstract}
Background: In this study, the effect of postoperative oral anticoagulation on the false lumen patency of the distal aorta in patients with acute type A aortic dissection was investigated.

Methods: Forty-one patients (32 male, 9 female; mean age 56.8 \pm 13.6 years; range, 30 to 84 years) who were diagnosed with acute type A aortic dissection and underwent surgical treatment in our clinic, and whose entire data of both control computed tomographic assessments and all postoperative follow-up visits could be accessed were enrolled. The patients were divided into two groups according to the type of surgical intervention that was performed. Computed tomography imaging of the patients were scanned and false lumen patency rates were evaluated. Besides oral anticoagulation, preoperative, intraoperative, and postoperative risk factors that may have affected false lumen patency secondary to acute type A aortic dissection were evaluated and statistically analyzed.
\end{abstract}

Results: Twenty-one patients (51.2\%) had concomitant hypertension. Thirty five $(85.4 \%)$ of the patients had the main symptom of angina. Sixteen patients $(39 \%)$ in Group 1 underwent ascending aortic replacement combined with aortic valve replacement (Bentall procedure); while 25 patients $(61 \%)$ in Group 2 underwent isolated ascending aortic replacement. Mean follow-up was $43.9 \pm 26.3$ (range: 5-120) months. No statistically significant difference was found between the study subgroups in any of the operation parameters except for cardiopulmonary bypass time $(\mathrm{p}=0.035)$ and cross-clamp time $(\mathrm{p}=0.002)$. Evaluation of the control contrast-enhanced tomographic imaging of the patients showed false lumen patency in the thorax in 34 patients $(82.9 \%)$ and in the abdominal region in 33 patients $(80.5 \%)$ When analyzing subgroups according to the type of surgical procedure, or indirectly anticoagulant use, no statistically significant difference was found in false lumen patency prevalence between the thoracic and abdominal groups $(\mathrm{p}=0.534$ and $\mathrm{p}=0.922)$.

Conclusion: No potential effect of postoperative anticoagulation on false lumen patency was found in cases with acute type A aortic dissection.

Keywords: Acute type A aortic dissection; false lumen; oral anticoagulation.

\section{$\ddot{O} Z$}

Amaç: Bu çalışmada akut tip A aort diseksiyonlu hastalarda, ameliyat sonrası oral antikoagülan kullanımının distal aorttaki sahte lümen açıklığı üzerine etkisi araştırıldı.

Calışma planı: Kliniğimizde akut tip A aort diseksiyonu tanısı konularak ameliyata alınan ve dosya bilgileri, poliklinik kontrolleri ile kontrol bilgisayarlı tomografi kayıtlarına eksiksiz olarak ulaşılabilen 41 hasta (32 erkek, 9 kadın; ort. yaş $56.8 \pm 13.6$ yıl; dağılım, 30-84 yıl) çalışmaya alındı. Uygulanan cerrahi tipine göre hastalar iki gruba ayrıldı. Hastaların bilgisayarlı tomografi görüntüleri taranarak, sahte lümenin açık kalma oranları değerlendirildi. Oral antikoagülasyon dışında, akut tip A aort diseksiyonuna sekonder olarak gelişen sahte lümen açıklığı üzerine etkili olabilecek ameliyat öncesi, ameliyat sırası ve ameliyat sonrası risk faktörleri araştırıldı ve istatistiksel analizi yapıld 1 .

Bulgular: Yirmi bir hastada (\%51.2) eşlik eden hipertansiyon vardı. Hastaların 35'inde (\%85.4) ana semptom göğüs ağrısı idi. Grup 1'deki 16 hastaya (\%39) mekanik aort kapak replasmanının eşlik ettiği çıkan aort replasmanı (Bentall operasyonu) uygulanırken, Grup 2'deki 25 hastaya (\%61) yalnızca çıkan aort replasmanı yapıldı. Ortalama takip süresi 43.9 \pm 26.3 (dağılım, 5-120) ay idi. Gruplar arasında ortalama kardiyopulmoner baypas süresi $(\mathrm{p}=0.035)$ ve ortalama kros-klemp süresi $(\mathrm{p}=0.002)$ dışında tüm ameliyat parametreleri açısından istatistiksel anlamlı fark bulunmadı. Hastaların kontrol kontrastlı tomografik görüntüleri değerlendirildiğinde, sahte lümenin toraks bölgesi için 34 hastada (\%82.9), batın bölgesi için ise 33 hastada (\%80.5) açık olduğu görüldü. Ameliyat tipine yani dolaylı olarak antikoagülan kullanımına göre ayrıntılı alt grup analizi yapıldığında hem toraks hem de batın bölgeleri için sahte lümen açık kalma oranları, gruplar arasında istatistiksel olarak anlamlı bulunmadı (sırasıyla, $\mathrm{p}=0.534$ ve $\mathrm{p}=0.922$ ).

Sonuç: Akut tip A aort diseksiyonlu hastalarda, ameliyat sonrası oral antikoagülan kullanımının sahte lümen açıklığı üzerine etkisi bulunmadı. Anahtar sözcükler: Akut tip A aort diseksiyonu; sahte lümen; oral antikoagülan.

Received: June 23, 2017 Accepted: March 29, 2018

Correspondence: Pelin Öztürk, MD. Ege Üniversitesi Tıp Fakültesi, Kalp ve Damar Cerrahisi Anabilim Dalı, 35040 Bornova, Izmir, Turkey. Tel: +90 532 - 6910374 e-mail: pelin.ozturk@yahoo.com 
Real and false lumens may develop in patients with acute type A aortic dissection (AAAD) due to tearing of the aortic intima. ${ }^{[1-4]}$ Such cases are treated with ascending aortic replacement (AAR) surgery; however additional aortic valve replacement (AVR) procedure may be necessary in patients who require anticoagulant therapy with warfarin sodium added to their postoperative medications. ${ }^{[3-6]}$ Since previous studies have revealed the potential correlation between false lumen patency (FLP) and rupture or widening of the lesion, we evaluated the effect of postoperative oral anticoagulation over FLP at thoracic and abdominal aortic segments.

\section{PATIENTS AND METHODS}

The medical records of patients admitted to our institute's emergency department with symptoms of aortic dissection, and who were surgically treated between April 2000 and April 2010 in our clinic after AAAD diagnosis according to transthoracic echocardiography (TTE) and thoracoabdominal contrast computed tomography (CT) evaluations were reviewed retrospectively. Patients diagnosed with DeBakey type 2 were excluded. A total of 41 patients who survived (32 male, 9 female; mean age 56.8 \pm 13.6 years; range, 30 to 84 years) and had complete data of medical records, outpatient follow-up visits, and control CT scans were enrolled in this study. The study was conducted in accordance with the methods described adhered to tenets of the Declaration of Helsinki, and the study protocol was approved by the Institutional Ethics Committee (Approval number: 2010; 10-9.1/6). This is a retrospective, non-comparative interventional case series, and all of the patients consented to our review of their medical records.

All participants of the study underwent surgical treatment performed via median sternotomy. The right subclavian artery was the route for arterial cannulation in 31 patients (75.6\%); however, the femoral artery was used for arterial cannulation in 10 instable patients $(24.4 \%)$ that required acute intervention. Right atrial venous cannulation was used in all patients. Group 1 consisted of 16 patients (39\%) who underwent AAR combined with aortic root replacement and mechanical AVR surgery (Bentall procedure); whereas Group 2 consisted of the remaining 25 patients (61\%) who underwent AAR combined with aortic valve resuspension surgery.

Antiaggregant medication with acetylsalicylic acid and anticoagulation with warfarin sodium was administered postoperatively in Group 1 patients; while Group 2 patients received only antiaggregant medication postoperatively. The efficacy of postoperative anticoagulation over FLP was evaluated after screening FLP at both thoracic and abdominal aortic segments in postoperative control contrast CT scans of each patient. A patent false lumen was defined in CT scans that depicted an obvious contrast transmission towards the false lumen; a partial thrombosis of the false lumen was defined in CT scans that depicted a filling defect according to a thrombus within the false lumen; and complete thrombosis of the false lumen was defined in CT scans that depicted any obvious contrast transmission towards the false lumen. Diagnosis of a patent or partially thrombosed false lumen was described as FLP; however, the presence of complete thrombosis was described as closed false lumen for further analysis.

The data were recorded on a computerized database and analyzed using SPSS version 15.0 statistical software (SPSS Inc., Chicago, Illinois, USA). After normality was tested with Kolmogorov-Smirnov test, chi-square and Fisher's chi-square tests were used for the statistical analysis of nominal data, Mann-Whitney $\mathrm{U}$ test was used for the statistical analysis of numerical data, and Spearman's Rho test was performed for the bivariate correlation analysis. A probability value of $<0.05$ was considered significant.

\section{RESULTS}

Age and gender distribution as well as mean body mass index (BMI) and follow-up time, presence of concomitant diseases (such as diabetes mellitus, hypertension, and chronic obstructive pulmonary disease-COPD), main symptoms at the time of first referral to the emergency department, and the period between the onset of symptoms and operation were given in Table 1.

No statistically significant difference was found between the two subgroups of the study in any of the operation parameters except in cardiopulmonary bypass time $(\mathrm{p}=0.035)$ and cross-clamp time $(\mathrm{p}=0.002)$. There was also no statistically significant difference in mean entubation time, intensive care unit (ICU) stay, total hospitalization time, and follow-up duration between both groups. No statistically significant difference was found in postoperative complication risks between the two study subgroups classified according to performed surgical procedure; which also means the administration of postoperative oral anticoagulation. However, a cerebrovascular accident and a severe nephrological complication requiring hemodialysis were seen in one (4\%) and two (8\%) patients, respectively in Group 2, neurologic and nephrological complications did not 
Table 1. Demographics

\begin{tabular}{|c|c|c|c|c|c|c|c|c|c|c|}
\hline & \multicolumn{3}{|c|}{ Group $1(n=16)$} & \multicolumn{3}{|c|}{ Group $2(n=25)$} & \multicolumn{3}{|c|}{ Overall $(n=41)$} & \multirow[b]{2}{*}{$p$} \\
\hline & $\mathrm{n}$ & $\%$ & Mean \pm SD & $\mathrm{n}$ & $\%$ & Mean \pm SD & $\mathrm{n}$ & $\%$ & Mean \pm SD & \\
\hline Age (year) & & & $52.8 \pm 12.1$ & & & $59.4 \pm 14.2$ & & & $56.8 \pm 13.6$ & $0.219 \dagger$ \\
\hline $\begin{array}{l}\text { Gender } \\
\quad \text { Female } \\
\text { Male }\end{array}$ & $\begin{array}{c}5 \\
11\end{array}$ & $\begin{array}{l}31.3 \\
68.8\end{array}$ & & $\begin{array}{c}4 \\
21\end{array}$ & $\begin{array}{l}16.0 \\
84.0\end{array}$ & & $\begin{array}{c}9 \\
32\end{array}$ & $\begin{array}{l}22.0 \\
78.0\end{array}$ & & $0.250 *$ \\
\hline $\begin{array}{l}\text { Concomitant disease } \\
\text { Diabetes mellitus } \\
\text { Hypertension } \\
\text { COPD }\end{array}$ & $\begin{array}{l}- \\
7 \\
-\end{array}$ & $\begin{array}{c}- \\
43.8 \\
-\end{array}$ & & $\begin{array}{c}1 \\
14 \\
2\end{array}$ & $\begin{array}{c}4.0 \\
56.0 \\
8.0\end{array}$ & & $\begin{array}{c}1 \\
21 \\
2\end{array}$ & $\begin{array}{c}2.4 \\
51.2 \\
4.9\end{array}$ & & $\begin{array}{c}0.418^{*} \\
0.444^{*} \\
246^{*}\end{array}$ \\
\hline Body surface area $\left(\mathrm{m}^{2}\right)$ & & & $1.89 \pm 0.16$ & & & $1.85 \pm 0.26$ & & & $1.86 \pm 0.23$ & $0.737 \dagger$ \\
\hline $\begin{array}{l}\text { Main symptom } \\
\text { Chest pain } \\
\text { Syncope } \\
\text { Malperfusion }\end{array}$ & $\begin{array}{c}14 \\
1 \\
1\end{array}$ & $\begin{array}{c}87.5 \\
6.3 \\
6.3\end{array}$ & & $\begin{array}{c}21 \\
2 \\
2\end{array}$ & $\begin{array}{c}84.0 \\
8.0 \\
8.0\end{array}$ & & $\begin{array}{c}35 \\
3 \\
3\end{array}$ & $\begin{array}{c}85.4 \\
7.3 \\
7.3\end{array}$ & & $\begin{array}{l}0.757^{*} \\
0.834^{*} \\
0.834^{*}\end{array}$ \\
\hline $\begin{array}{l}\text { Period between the onset } \\
\text { of symptoms and surgical } \\
\text { intervention (hours) }\end{array}$ & & & $17.2 \pm 16.7$ & & & $17.6 \pm 15.6$ & & & $17.5 \pm 15.8$ & $0.925 \dagger$ \\
\hline Follow-up (months) & & & $54.7 \pm 33.0$ & & & $37.1 \pm 18.8$ & & & $44.0 \pm 26.4$ & $0.105 \dagger$ \\
\hline
\end{tabular}

occur in Group 1 patients $(\mathrm{p}=0.418$ and $\mathrm{p}=0.246$, respectively). One patient in Group 1 (6.2\%) and four patients in Group $2(16 \%)$ developed pneumonia $(\mathrm{p}=0.352)$. Sepsis was seen in one patient in Group 1 (6.2\%); however, it was not diagnosed in any patients in Group $2(\mathrm{p}=0.478)$.

After screening control contrast CT scans of all study participants, FLP was found in 34 (82.9\%) thoracic, and $33(80.5 \%)$ abdominal aortic segments. When detailed subgroup analysis was performed according to the administration of postoperative oral anticoagulation related to the type of surgical procedure, FLP at thoracic aortic segment was present in 14 out of 16 patients $(87.5 \%)$ who were prescribed oral anticoagulation after they underwent Bentall procedure with mechanical AVR surgery. Among them, FLP at abdominal aortic segment was evident in 13 patients $(81.3 \%)$. However, FLP at thoracic aortic segment was revealed in 20 out of 25 patients $(80 \%)$ without any need for postoperative oral anticoagulation

Table 2. The effect of postoperative anticoagulation over false lumen patency at thoracic and abdominal aortic segments

\begin{tabular}{|c|c|c|c|c|c|c|c|}
\hline & \multicolumn{2}{|c|}{$\begin{array}{c}\text { Group } 1 \\
\text { Warfarin }(+) \\
(\mathrm{n}=16)\end{array}$} & \multicolumn{2}{|c|}{$\begin{array}{c}\text { Group } 2 \\
\text { Warfarin }(-) \\
(\mathrm{n}=25)\end{array}$} & \multicolumn{2}{|c|}{$\begin{array}{c}\text { Overall } \\
(\mathrm{n}=41)\end{array}$} & \multirow[b]{2}{*}{$p^{*}$} \\
\hline & $\mathrm{n}$ & $\%$ & $\mathrm{n}$ & $\%$ & $\mathrm{n}$ & $\%$ & \\
\hline False lumen thoracic segment & & & & & & & 0.534 \\
\hline Patent & 14 & 87.5 & 20 & 80 & 34 & 82.9 & \\
\hline Thrombosed & 2 & 12.5 & 5 & 20 & 7 & 17.1 & \\
\hline False lumen abdominal segment & & & & & & & 0.922 \\
\hline Patent & 13 & 81.3 & 20 & 80 & 33 & 80.5 & \\
\hline Thrombosed & 3 & 18.8 & 5 & 20 & 8 & 19.5 & \\
\hline
\end{tabular}

* Statistical analysis performed with Chi-square test. 
as they underwent AAR surgery combined with aortic valve resuspension procedure. Screening of abdominal aortic segment with CT scans also revealed that FLP was present in $80 \%$ of the patients in Group 2 (Table 2). No statistically significant difference was found in FLP for both thoracic and abdominal aortic segments between study subgroups. Control contrast angio-CT scans designating patent (Figure 1a), partial thrombosis (Figure 1b), and complete thrombosis (Figure 1c) of false lumens, as well as a false lumen that was found closed at thoracic and patent at abdominal aortic segments (Figure 1d) were presented in Figure 1.

Of the entire study population, only three patients (7.3\%) had closed false lumen both at thoracic and abdominal aortic segments. The remaining 38 patients were diagnosed with FLP at either thoracic or abdominal aortic segments. Statistical analyses revealed no significant difference between the presence of closed false lumen and any of the following: age, gender, concomitant diagnosis of diabetes or hypertension, performed operation type, time period between
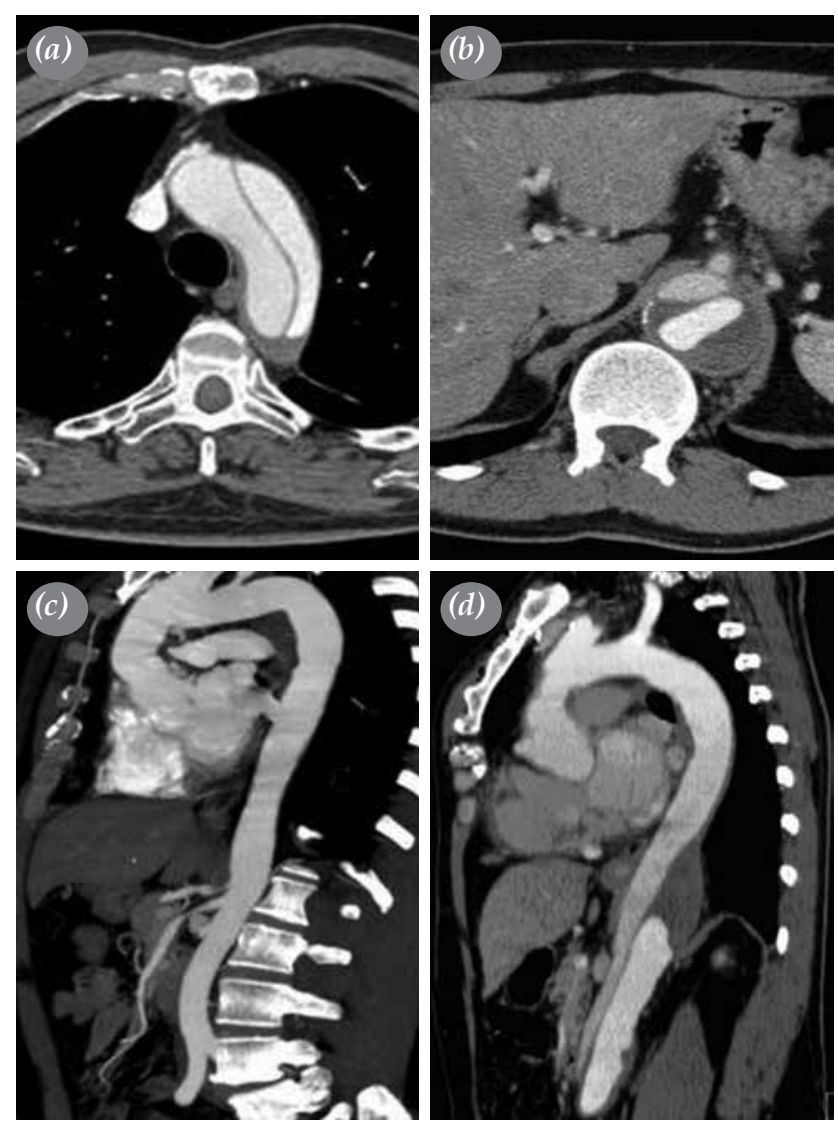

Figure 1. Control contrast angio-computed tomography scans (a) designating patent, (b) partial thrombosis, and (c, d) complete thrombosis of false lumens, as well as a false lumen that was found closed at thoracic and patent at abdominal aortic segments. the onset of symptoms and surgical intervention, cardiopulmonary bypass time and cross-clamp time, total circulatory arrest (TCA) time, mean TCA temperature, total amount of requested cardioplegia and blood product requirement, the overall need for inotropic agents, total entubation time, incidence of postoperative complications, as well as the total length of hospitalization, and ICU stay. However, presence of concomitant COPD and/or lower BMI were found to be related with a closed false lumen in our study population.

\section{DISCUSSION}

Aortic dissection, which was firstly described in literature 200 years ago, is the most common catastrophic, mortal, and urgent disease of the aorta with its incidence of $0.5-3 / 100000 .^{[1-3]}$ Excision of the primary intimal tear is the aim of dissection surgeries. Aortic valve interventions including AAR combined with AVR, subtotal root replacement, David, Bentall, Bio-Bentall, or Cabrol procedures may be required in cases with dilated aortic root, tear involving coronary cusps, or severe aortic valve deformation. ${ }^{[7-11]}$ Etz et al. ${ }^{[1]}$ reported the surgical outcomes of 597 patients who underwent Bentall procedure, and reported subgroup analysis showed that implanted aortic valve type did not have any impact over their early and late surgical outcomes, including patients aged between 50 and 70 years. The authors also concluded that Bentall procedure with mechanical aortic valve implantation was the gold standard surgical approach, even in the elderly population. Considering the younger mean age and higher life expectations of our study population, we also performed Bentall procedure combined with the implantation of mechanical aortic valve prosthesis in all of our study participants diagnosed with aortic dissection and concomitant aortic valve disorder. Any valve sparing techniques or the implantation of biological aortic valve grafts were not used in any of our study patients.

Within 5-10 years after AAAD surgery, approximately $10-40 \%$ of the treated patients require reoperations for distal aortic segments; which may also affect these patients' survival. ${ }^{[12-14]}$ The literature defines age, presence of any novel neurological deficits at the time of referral, and preoperative diagnosis of thrombosis located in the ascending aorta are defined as major risk factors for late term mortality after AAAD surgery; furthermore, patency of false lumen is also described as a surgical technique related parameter for mortality in such patients..$^{[14-20]}$ The literature reports the frequency of FLP after AAAD surgery to be between $40 \%$ and $85 \% .^{[2,13,14,21]}$ We also 
found FLP rates of $82.9 \%$ and $80.5 \%$ for thoracic and abdominal aortic segments, respectively, in our study population; which is consistent with the recent literature.

Although FLP is defined as a major risk factor for dilatation of the distal aorta and more severe lateterm outcomes in many studies, ${ }^{[12-15,21]}$ some authors reported no significant correlations between FLP and survival rate, as well as between FLP and the need for any aortic reoperations when they compared those with patients with a thrombosis of false lumen. ${ }^{[2,19]}$ In a study published in 2011, Song et al. ${ }^{[22]}$ reported lower frequencies of thrombotic complications and malperfusion in patients with a partial thrombosis of false lumen. Bernard et al. ${ }^{[15]}$ published the impacts of rapid enlargement of the lesion, advanced age, and postoperative FLP over late-term aortic complications as well as mortality. Some authors reported that annual dilatation rate of aortic diameter was found to be higher in cases with either patent or partial thrombosis of false lumens when compared to those with a thrombosis. ${ }^{[2,20,22]}$ Fattouch et al. ${ }^{[23]}$ reported annual aortic diameter enlargement rates of $2.8 \pm 0.4 \mathrm{~mm}$ and $1.1 \pm 0.2 \mathrm{~mm}$ in cases with patent and false lumen thrombosis, respectively. Fattori et al. ${ }^{[21]}$ also found these rates as $3.7 \mathrm{~mm}$ and $1.1 \mathrm{~mm}$, respectively. Furthermore, Sakaguchi et al. ${ }^{[24]}$ reported increased probability of FLP in cases with preoperatively diagnosed hypertension and in those with preoperative descending thoracic aortic diameter of $\geq 35 \mathrm{~mm}$. Reeger et al. ${ }^{[20]}$ found increased probability for a false lumen thrombosis in females, cases with lower body surface area (BSA), and those with preoperative higher EuroSCORES; however, young males were found to be more prone to FLP. We did not find any correlation between FLP and any of the following: age, gender, concomitant diagnosis of diabetes or hypertension, performed operation type, length of time between the onset of symptoms and surgical intervention, cardiopulmonary bypass time and cross-clamp time, TCA time, mean TCA temperature, total amount of requested cardioplegia and transfusion requirement, the overall need for inotropic agents, total intubation time, incidence of postoperative complications, as well as the durations of total hospitalization, and ICU stay. However, increased probability for a closed false lumen was found in patients with comorbid COPD in our study population. Higher rates of false lumen thrombosis was also found to be frequent in those with lower BMI and/or BSA; which was consistent with the results of Reeger et al. ${ }^{[20]}$

Recent literature has suggested that oral anticoagulation associated with mechanical valve surgeries or any other interventions may have an effect over FLP. ${ }^{[22,25,26]}$ In a study published in 2007, Gariboldi et al. ${ }^{[25]}$ reported higher probability of FLP in patients who took anticoagulant medication postoperatively. The authors stated that these were the results of univariable analysis; however multivariable analysis revealed no correlation between oral anticoagulation and FLP. Moreover, they did not find any impact of oral anticoagulation on the need for reoperation of the distal aorta. In accordance with the results of von Kodolitsch et al., ${ }^{[19]}$ we also found no statistically significant correlation between postoperative oral anticoagulation and FLP in our study population.

In accordance with the literature, the early and mid-term surgical outcomes after aortic root and valve replacement with mechanical valve prosthesis were considerably gratifying in our younger patients with AAAD and widened aortic root; which was commonly associated with Marfan's syndrome. Since the reoperation of aortic valve and root may carry significant morbidity and mortality risks in these patients, the outcomes of surgical interventions without any need for postoperative oral anticoagulation are still doubtful as increased risk of early aortic valve insufficiency may be evident secondary to valve surgery approaches except from the implantation of mechanical valve prosthesis.

In conclusion, the potential causes of false lumen patency after an acute type A aortic dissection surgery and the effect of oral anticoagulation over false lumen patency are still not well known. We could not find any potential effects of postoperative anticoagulation over false lumen patency in patients with acute type A aortic dissection.

\section{Declaration of conflicting interests}

The authors declared no conflicts of interest with respect to the authorship and/or publication of this article.

\section{Funding}

The authors received no financial support for the research and/or authorship of this article.

\section{REFERENCES}

1. Elsayed RS, Cohen RG, Fleischman F, Bowdish ME. Acute Type A Aortic Dissection. Cardiol Clin 2017;35:331-45.

2. Kimura N, Tanaka M, Kawahito K, Yamaguchi A, Ino T, Adachi $\mathrm{H}$. Influence of patent false lumen on long-term outcome after surgery for acute type A aortic dissection. J Thorac Cardiovasc Surg 2008;136:1160-6.

3. Tsai TT, Trimarchi S, Nienaber CA. Acute aortic dissection: perspectives from the International Registry of Acute Aortic Dissection (IRAD). Eur J Vasc Endovasc Surg 2009;37:149-59. 
4. Reece TB, Green GR, Kron IL. Aortic dissection. In: Cohn LH, editor. Cardiac Surgery in the Adult. New York: McGraw-Hill Companies; 2008. p. 1195-222.

5. Tang PC, Badami A, Akhter SA, Osaki S, Lozonschi L, Kohmoto T, et al. Efficacy of aortic valve resuspension in establishing valve competence in acute type a dissections. Ann Thorac Surg 2017;103:1460-6.

6. Saczkowski R, Malas T, Mesana T, de Kerchove L, El Khoury G, Boodhwani M. Aortic valve preservation and repair in acute Type A aortic dissection. Eur J Cardiothorac Surg 2014;45:220-6.

7. Yağdi T, Atay Y, Cikirikçioğlu M, Boğa M, Posacioğlu $\mathrm{H}$, Ozbaran M, et al. Determinants of early mortality and neurological morbidity in aortic operations performed under circulatory arrest. J Card Surg 2000;15:186-93.

8. David TE, Feindel CM. An aortic valve-sparing operation for patients with aortic incompetence and aneurysm of the ascending aorta. J Thorac Cardiovasc Surg 1992;103:617-21.

9. Di Eusanio M, Murana G, Cefarelli M, Mazzola A, Di Bartolomeo R. The Bentall procedure with a biological valved conduit: substitute options and techniques. Multimed Man Cardiothorac Surg 2014;2014.

10. Kirklin JK, Smith D, Novick W, Naftel DC, Kirklin JW, Pacifico AD, et al. Long-term function of cryopreserved aortic homografts. A ten-year study. J Thorac Cardiovasc Surg 1993;106:154-65.

11. Etz CD, Bischoff MS, Bodian C, Roder F, Brenner R, Griepp $\mathrm{RB}$, et al. The Bentall procedure: is it the gold standard? A series of 597 consecutive cases. J Thorac Cardiovasc Surg 2010;140:64-70.

12. Yeh $\mathrm{CH}$, Chen MC, Wu YC, Wang YC, Chu JJ, Lin PJ. Risk factors for descending aortic aneurysm formation in medium-term follow-up of patients with type A aortic dissection. Chest 2003;124:989-95.

13. Immer FF, Hagen U, Berdat PA, Eckstein FS, Carrel TP. Risk factors for secondary dilatation of the aorta after acute type A aortic dissection. Eur J Cardiothorac Surg 2005;27:654-7.

14. Halstead JC, Meier M, Etz C, Spielvogel D, Bodian C, Wurm M, et al. The fate of the distal aorta after repair of acute type A aortic dissection. J Thorac Cardiovasc Surg 2007;133:127-35.

15. Bernard Y, Zimmermann H, Chocron S, Litzler JF, Kastler B, Etievent JP, et al. False lumen patency as a predictor of late outcome in aortic dissection. Am J Cardiol 2001;87:1378-82.

16. Erbel R, Aboyans V, Boileau C, Bossone E, Bartolomeo RD, Eggebrecht H, et al. 2014 ESC Guidelines on the diagnosis and treatment of aortic diseases: Document covering acute and chronic aortic diseases of the thoracic and abdominal aorta of the adult. The Task Force for the Diagnosis and
Treatment of Aortic Diseases of the European Society of Cardiology (ESC). Eur Heart J 2014;35:2873-926.

17. Hiratzka LF, Bakris GL, Beckman JA, Bersin RM, Carr VF, Casey DE Jr, et al. 2010 ACCF/AHA/AATS/ACR/ ASA/SCA/SCAI/SIR/STS/SVM guidelines for the diagnosis and management of patients with Thoracic Aortic Disease: a report of the American College of Cardiology Foundation/American Heart Association Task Force on Practice Guidelines, American Association for Thoracic Surgery, American College of Radiology, American Stroke Association, Society of Cardiovascular Anesthesiologists, Society for Cardiovascular Angiography and Interventions, Society of Interventional Radiology, Society of Thoracic Surgeons, and Society for Vascular Medicine. Circulation 2010;121:e266-369.

18. Li D, Ye L, He Y, Cao X, Liu J, Zhong W, et al. False Lumen Status in Patients With Acute Aortic Dissection: A Systematic Review and Meta-Analysis. J Am Heart Assoc 2016;5. pii: e003172.

19. von Kodolitsch Y, Wilson O, Schüler H, Larena-Avellaneda A, Kölbel T, Wipper S, et al. Warfarin anticoagulation in acute type A aortic dissection survivors (WATAS). Cardiovasc Diagn Ther 2017;7:559-571.

20. Regeer MV, Martina B, Versteegh MI, de Weger A, Klautz RJ, Schalij MJ, et al. Prognostic implications of descending thoracic aorta dilation after surgery for aortic dissection. J Cardiovasc Comput Tomogr 2017;11:1-7.

21. Fattori R, Bacchi-Reggiani L, Bertaccini P, Napoli G, Fusco $\mathrm{F}$, Longo M, et al. Evolution of aortic dissection after surgical repair. Am J Cardiol 2000;86:868-72.

22. Song SW, Yoo KJ, Kim DK, Cho BK, Yi G, Chang BC. Effects of early anticoagulation on the degree of thrombosis After repair of acute DeBakey type I aortic dissection. Ann Thorac Surg 2011;92:1367-74.

23. Fattouch K, Sampognaro R, Navarra E, Caruso M, Pisano $\mathrm{C}$, Coppola G, et al. Long-term results after repair of type a acute aortic dissection according to false lumen patency. Ann Thorac Surg 2009;88:1244-50.

24. Sakaguchi G, Komiya T, Tamura N, Kimura C, Kobayashi $\mathrm{T}$, Nakamura $\mathrm{H}$, et al. Patency of distal false lumen in acute dissection: extent of resection and prognosis. Interact Cardiovasc Thorac Surg 2007;6:204-7.

25. Gariboldi V, Grisoli D, Kerbaul F, Giorgi R, Riberi A, Metras D, et al. Long-term outcomes after repaired acute type A aortic dissections. Interact Cardiovasc Thorac Surg 2007;6:47-51.

26. Kantelhardt SR, Pasnoori V, Varma J, Rezazadeh A, Dawn B. Recurrent aortic dissection in Marfan's syndrome: possible effects of anticoagulation. Cardiol Rev 2003;11:240-3. 